\title{
EVALUATION OF OCCUPATIONAL SAFETY AND HEALTH IN PT PANTJA SIMPATI
}

\section{EVALUASI KESELAMATAN DAN KESEHATAN KERJA DI PT PANTJA SIMPATI}

\author{
Ahmad Faqih Solansa ${ }^{a^{*}}$, Henra Nanang Sukma ${ }^{\mathrm{a}}$, M Sudiyamto $^{\mathrm{a}}$ \\ a Teknik Grafika, Politeknik Negeri Media Kreatif, Indonesia \\ *Email: Ahmadfaqihsolansa@gmail.com
}

\begin{abstract}
Every production process in a company is inseparable from all the dangers of disease and occupational accidents for workers. So in a company it is necessary to implement occupational safety and health in order to reduce and prevent occupational diseases and accidents. In carrying out occupational safety and health at PT Pantja Simpati, PT Pantja Simpati has several problems that can cause illness and work accidents such as unavailability of personal protective equipment, non-functioning air vents, employees smoking in the production room, employees drinking in the production section. part. areas, fire fighting equipment lacks lighting, damaged ceilings or roofs, untidy cables, and slippery production floors. Ways to avoid work accidents such as providing PPE and APAR, repairing damaged equipment, and taking firm action against workers. From the problems found, the implementation of occupational safety and health at PT Pantja Simpati is still not good.
\end{abstract}

Keywords-Occupational Safety and Health, $5 W+1 H$

Abstrak - Setiap proses produksi di suatu perusahaan tidak terlepas dari segala bahaya penyakit dan kecelakaan kerja bagi para pekerja. Maka dalam suatu perusahaan perlu adanya penerapan keselamatan dan kesehatan kerja guna mengurangi dan mencegah penyakit dan kecelakaan kerja. Dalam melaksanakan keselamatan dan kesehatan kerja di PT Pantja Simpati, PT Pantja Simpati memiliki beberapa permasalahan yang dapat menyebabkan timbulnya penyakit dan kecelakaan kerja seperti tidak tersedianya alat pelindung diri, ventilasi udara yang tidak berfungsi, karyawan merokok di ruang produksi, karyawan minum di bagian produksi. bagian. daerah, peralatan pemadam kebakaran kurang penerangan, plafon atau atap rusak, kabel tidak tertata rapi, dan lantai produksi licin. Cara-cara menghindari kecelakaan kerja seperti pemberian APD dan APAR, memperbaiki peralatan yang rusak, dan menindak tegas pekerja. Dari permasalahan yang ditemukan, implementasi keselamatan dan kesehatan kerja di PT Pantja Simpati masih kurang baik

Kata Kunci- Keselematan dan Kesehatan Kerja, 5W+1H

PENDAHULUAN

Undang-Undang No. 13 Tahun 2003
Pasal 86 Ayat 1 dan 2 menyatakan "setiap pekerja memiliki hak untuk mendapatkan 
perlindungan atas keselamatan dan kesehatan kerja, moral dan kesusilaan juga perlakuan yang sesuai dengan harkat, martabat manusia dan nilai-nilai agama guna melindungi keselamatan pekerja untuk produktivitas kerja yang optimal, diselenggarakan upaya keselamatan dan kesehatan kerja

Kegiatan usaha pada level perusahaan tentunya telah menjalankan fungsi-fungsi manajemen seperti pada bagian pengorganisasian, pelaksanaan, dan pengawasan. Pekerja tidak akan terlepas dalam hubungannya dengan manajemen dimana pekerja tersebut beraktivitas. Kedua bagian ini akan sangat berkaitan untuk dapat meningkatkan produktivitas kerja, agar sistem kerja yang dilakukan menjadi sangat efektif, maka salah satu faktor yang sangat penting untuk diperhatikan adalah keselamatan dan kesehatan kerja

Perusahaan yang baik adalah perusahaan yang benar-benar selalu memperhatikan dan menjamin keselamatan dan kesehatan karyawannya dari kecelakaan kerja dan juga penyakit yang ditimbulkan dari lingkungan kerjanya itu sendiri, karena hal tersebut sangat mempengaruhi dalam melakukan proses produksi suatu pekerjaan. Jika kecelakaan kerja terjadi, maka proses produksi akan berhenti sejenak, waktu produksi terbuang percuma, target produksi dapat berkurang, juga mental para karyawan yang sedang bekerja akan sedikit terganggu akibat kecelakaan kerja yang terjadi, dan perusahaan pun akan mengalami kerugian akibat tanggungan biaya yang disebabkan oleh kecelakaan kerja tersebut. Maka dari itu, keselamatan dan kesehatan kerja harus diperhatikan dengan serius oleh setiap tenaga kerja, agar produksi dalam pekerjaan dapat berjalan dengan lancar dan aman. Sehingga target perusahaan pun dapat terpenuhi sesuai dengan target yang sudah ditentukan

Selama kurang lebih 1 bulan penulis melakukan Praktik Kerja Industri di PT. Pantja Simpati, penulis mengamati penerapan K3 di PT. Pantja Simpati dan penulis menemukan kegiatan saat memproduksi di PT. Pantja Simpati terdapat permasalahan aktivitas kerja dan kurangnya perawatan peralatan kerja yang dapat mengancam keselamatan dan kesehatan para pekerjanya. Dari permasalahan yang ditemukan di PT. Pantja Simpati terdapat banyak sekali resiko terjadinya kecelakaan kerja

Berdasarkan hasil di lapangan saat penulis melakukan Praktik Kerja Industri di PT. Pantja Simpati, penulis menemukan beberapa indikasi masalah pada Keselamatan dan Kesehatan Kerja (K3), seperti : a. Tidak tersedianya Alat Pelindung Diri (APD). b, Ventilasi udara yang tidak berfungsi c, Masih ditemukan karyawan merokok di area produksi d, Masih ditemukan karyawan 
minum di area produksi e, Kurangnya alat pemadam api ringan (APAR) f, Plafon atau Atap yang sudah rusak

g, Kabel-kabel yang tidak tersusun dengan rapih $\mathrm{h}$, Lantai produksi licin

\section{METODE PENELITIAN}

Metode yang penulis gunakan dalam membuat karya tulis Tugas Akhir ini adalah metode penulisan deskriptif, Penulis menggunakan beberapa metode untuk pengumpulan data dalam pembuatan Tugas Akhir ini. Hal ini bertujuan untuk memperoleh informasi yang lebih akurat dalam melengkapi data serta memperoleh solusi yang baik untuk memecahkan masalah yang ada dalam pembahasan Tugas Akhir ini. Metode yang digunakan adalah:

a. Metode Obeservasi Lapangan\

Metode ini dilakukan dengan melihat langsung proses produksi pada saat melakukan praktik industri

b. Metode Kepustakaan

Pelaksanaan ini dilakukan dengan cara mengumpulkan dan mempelajari berbagai sumber tertulis dan data-data serta informasi yang berhubungan dengan masalah yang dibahas pada penulisan ini. Sumber tersebut berupa buku-buku, jurnal, dan datadata lainnya yang bersumber dari internet. Alat Pelindung Diri (APD) adalah seperangkat alat yang digunakan oleh tenaga kerja untuk melindungi seluruh/sebagian tubuhnya terhadap kemungkinan adanya potensi bahaya/kecelakaan kerja. APD dipakai sebagai upaya terakhir dalam usaha melindungi tenaga kerja apabila usaha rekayasa (engineering) dan administratif tidak dapat dilakukan dengan baik. APD juga merupakan kelengkapan yang wajib digunakan saat bekerja sesuai kebutuhan untuk menjaga keselamatan pekerja itu sendiri dan orang di sekelilingnya. (Johanes, 2017:14)

Perlengkapan pelindung diri termasuk semua pakaian dan aksesories pekerjaan lain yang dirancang untuk menciptakan sebuah penghalang terhadap bahaya tempat kerja. Penggunaan APD harus tetap dikontrol oleh pihak yang bersangkutan, khususnya di sebuah tempat kerja. (Johanes, 2017:14)

Suma'mur (dalam Johanes, 2017:14), alat pelindung diri adalah suatu alat yang dipakai untuk melindungi diri atau tubuh terhadap bahaya-bahaya kecelakaan kecelakaan kerja. Alat pelindung diri merupakan salah satu cara untuk mencegah kecelakaan dan secara teknis APD tidaklah sempurna untuk mencegah kecelakaan yang terjadi

c. Metode Dokumentasi

Pelaksanaan ini dilakukan dengan cara megumpulkan dokumentasi yang terjadi di PT Pantja Simpati yang berhubungan 
dengan masalah yang dibahas pada penulisan ini

\section{HASIL DAN PEMBAHASAN}

PT Pantja Simpati adalah perusahaan yang bergerak di bidang Printing dan pembuatan Packaging yang memproduksi Buku, Kemasan, Al-Qur'an Kalender, Agenda, dimana dalam proses kerjanya tidak lepas dari faktor bahaya sehingga beresiko terjadinya kecelakaan kerja. Maka dari itu perlu adanya tindakan pencegahan terhadap faktor bahaya tersebut sebelum terjadi suatu insiden sehingga kerugian dapat diminimalkan atau bahkan dihilangkan.

Berdasarkan observasi lapangan dan dokumentasi di PT Pantja Simpati, penulis menemukan beberapa permasalahan yang bisa menyebabkan resiko terjadinya kecelakaan kerja, permasalahannya seperti tidak tersedianya alat pelindung diri, ventilasi udara yang tidak berfungsi, masih ditemukan karyawan merokok di area produksi, masih ditemukan karyawan minum di area produksi, kurangnya alat pemadam api ringan (APAR), palfon atau atap yang sudah rusak, kabelkabel yang tidak tersusun dengan rapih, dan lantai produksi yang licin.

1. Penerapan Keselamatan Kesehatan Kerja di PT Pantja Simpati

Penerapan keselamatan dan kesehatan di PT Pantja Simpati masih kurang baik dikarenakan masih ditemukan beberapa permasalahan yang bisa menyebabkan kecelakaan kerja, mengganggu kesehatan para pekerja dan bisa merugikan bagi perusahaan jika terjadinya kecelakaan kerja.

Permasalah tersebut antara lain:

a. Tidak tersedianya alat pelindung diri (APD)
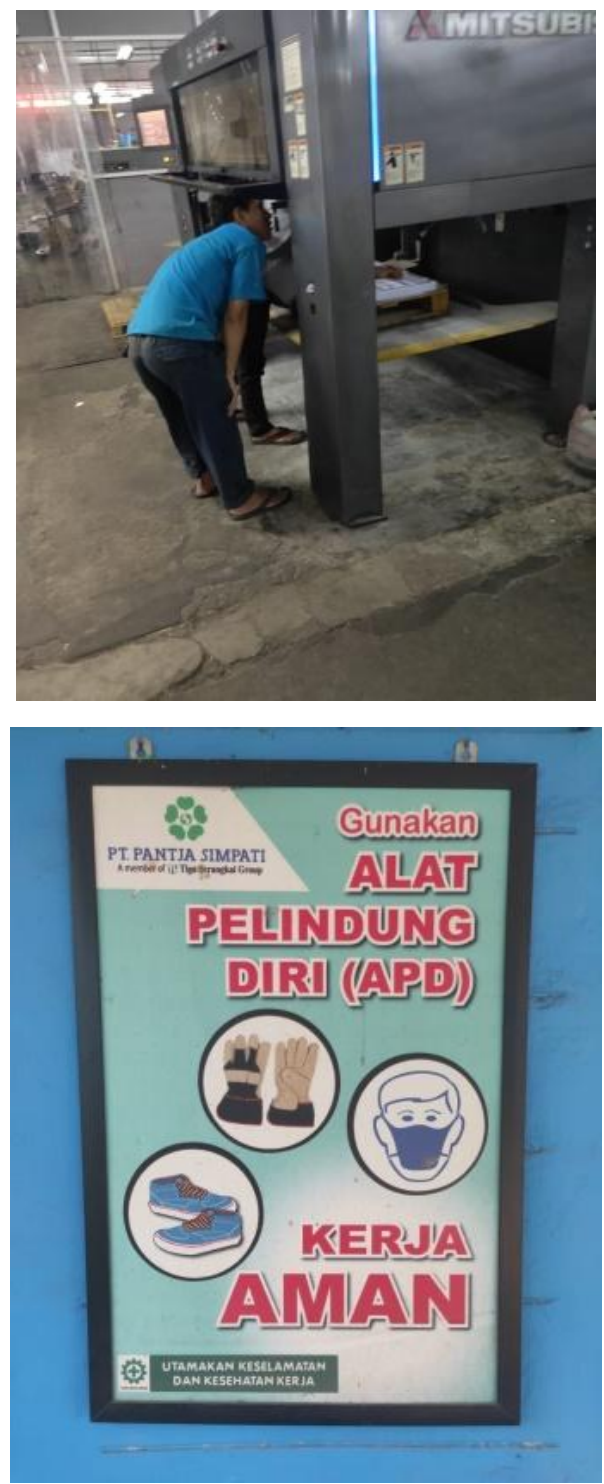

Gambar 4.1 Pekerja yang tidak menggunakan APD dan Rambu-rambu menggunakan APD 
1) Tidak tersedianya alat pelindung diri adalah kesalahan dari perusahaan yang membuat para pekerja tidak menggunakan alat pelindung diri saat bekerja dan bisa menyebabkan para pekerja beresiko tinggi terjadi kecelakaan kerja saat bekerja.

2) Penerapan keselamatan dan kesehatan kerja yang baik adalah perusahaan menyediakan alat pelindung diri (APD) agar para pekerja menggunakan alat pelindung diri saat bekerja.

b. Ventilasi udara yang tidak berfungsi

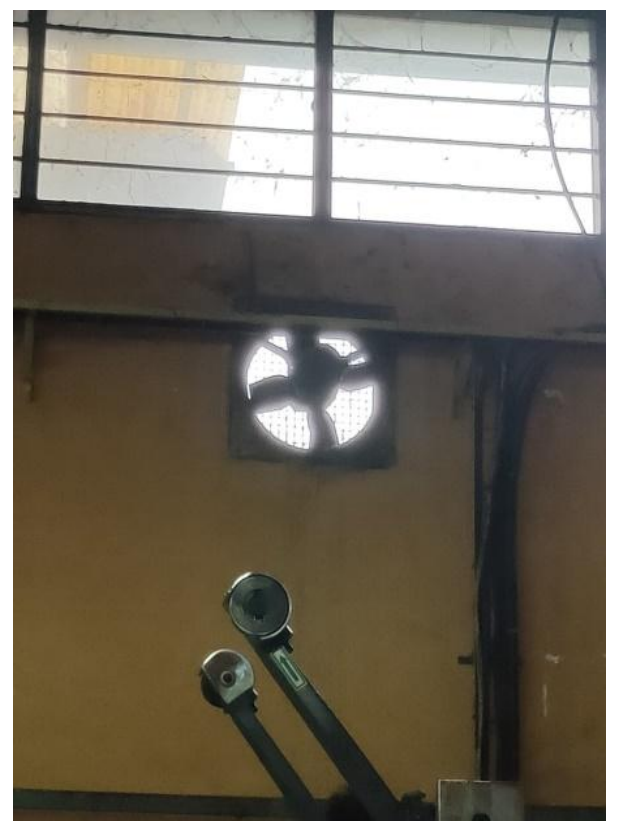

Gambar 4.2 Ventilasi udara yang tidak berfungsi

Ventilasi udara yang tidak berfungsi dikarenakan sudah rusak dan tidak diperbaiki oleh pihak perusahaan dan membuat sirkulasi udara di ruangan produksi kurang baik dan bisa mengganggu kesehatan bagi pekerja. c. Masih ditemukan karyawan merokok di area produksi

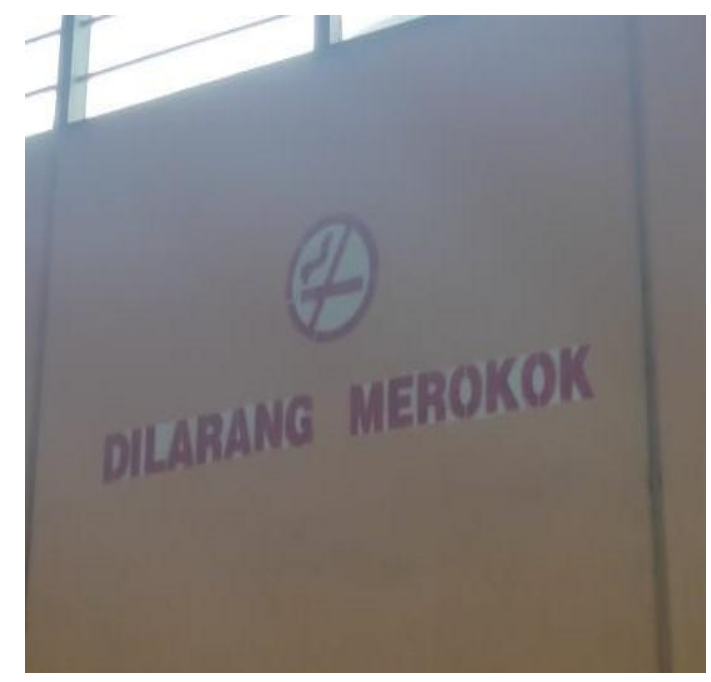

Gambar 4.3 Rambu-rambu kawasan dilarang merokok

Karyawan merokok di area produksi adalah kesalahan besar dikarenakan merokok bisa menyebabkan kecelakaan kerja seperti kebakaran maka dari itu perusahaan harus menindak tegas untuk karyawan yang merokok di area produksi.

d. Masih ditemukan karyawan minum di area produksi

Minum di area produksi itu salah dikarenakan saat minum bisa membuat air tumpah, air yang tumpah menyebabkan mesin konslet akibat tumpahan air minum tersebut dan bisa membuat lantai produksi licin akibat tumpahan air tersebut.

e. Kurangnya alat pemadam api ringan (APAR) 


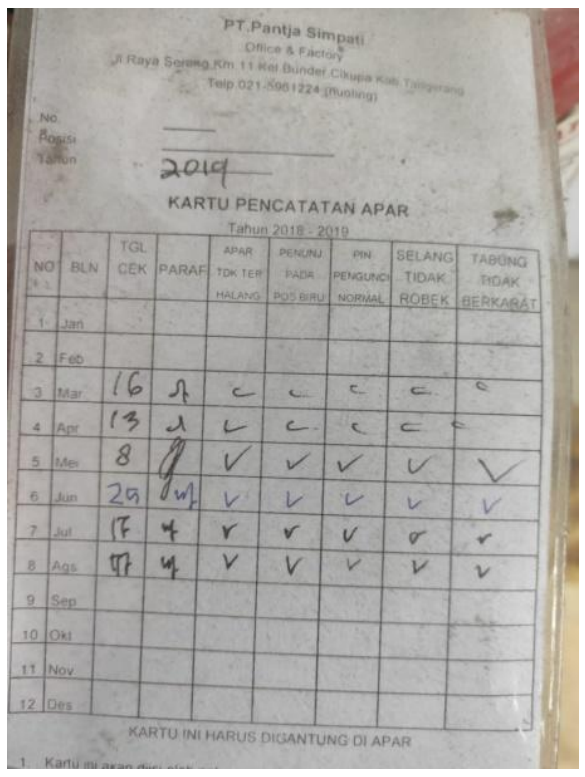

Gambar 4.4 Kartu pengecekan alat pemadam api ringan (APAR)

Alat pemadam api ringan sangat dibutuhkan saat bekerja dikarenakan seketika terjadi kebakaran kecil bisa digunakan untuk memadamkan api yang muncul, dan sebaiknya alat pemadam api ringan di cek setiap bulannya.

f. Plafon atau atap yang sudah rusak

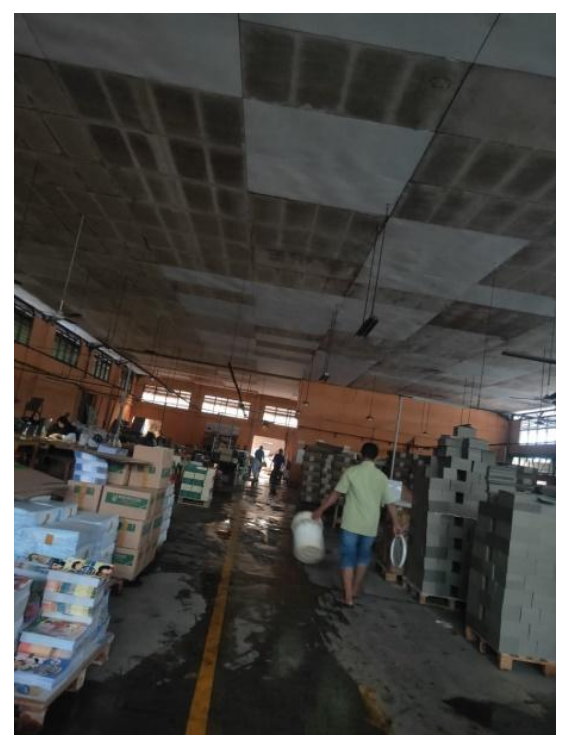

Gambar 4.5 Banjir di area produksi
Plafon atau atap yang sudah rusak bisa menyebabkan bocor saat hujan sehingga bisa menyebabkan banjir di area produksi dan bisa membuat rusak mesin jika terendam air.

g. Kabel-kabel yang tidak tersusun dengan rapih

Kabel-kabel yang tidak tersusun dengan rapih juga penerpan keselamatan kesehatan yang kurang dikarenakan bisa menyebabkan kecelakaan kerja, bisa menyebabkan para pekerja tersandung dan membuat kabel tersebut putus.

h. Lantai produksi yang licin

Lantai produksi yang licin bisa disebabkan dikarenakan kebocoran atau tumpahan minyak dan air yang membuat lantai tersebut licin dan bisa membuat para pekerja terpleset dan terjatuh dikarenakan lantai produksi yang licin.

\section{Resiko-Resiko Terjadinya Kecelakaan Kerja Berdasarkan Permasalahan Yang Ditemukan}

Resiko-resiko yang terjadi berdasarkan permasalahan yang ditemukan di PT Pantja Simpati seperti berikut:

a. Tidak tersedianya alat pelindung diri

Tidak tersedianya Alat Pelindung Diri dari perusahaan yang terjadi adalah karyawan tidak memakai alat pelindung diri saat bekerja. Dari resiko-resiko yang sudah penulis jabarkan seperti tertimpa barang 
berat, terjatuh, terbentur, dan terjepit, walaupun alat pelindung diri tidak bisa mengurangi kecelakaan kerja, tetapi setidaknya bisa mengurangi luka akibat kecelakaan kerja yang terjadi, sehingga bisa membuat rasa aman untuk para pekerja.

b. Ventilasi udara yang tidak berfungsi

Ventilasi udara yang tidak berfungsi dan sirkulasi udara yang kurang baik tidak akan menyebabkan kecelakaan kerja, tetapi terjadinya resiko kesehatan bagi para pekerja.

Resikonya kesehatan yang didapat bagi pekerja adalah para pekerja menjadi sesak nafas karena sirkulasi udara yang tidak baik dan para pekerja merasa tidak nyaman saat bekerja karena suhu udara yang tinggi diakibatksan sirkulasi udara yang tidak baik.

c. Masih ditemukan karyawan merokok di area produksi

Karyawan masih ditemukan merokok di area produksi adalah kesalahan sangat besar, karena merokok di area produksi bisa menyebabkan terjadinya kebakaran, disebabkan karena di ruang produksi berisi bahan-bahan yang mudah terbakar seperti kertas, gas, dan lain-lain.

Akibatnya adalah kerugian yang sangat besar bagi para karyawan karena kehilangan pekerjaan dan bisa menyebabkan kematian bagi para pekerja sendiri. Kerugian untuk perusahaan adalah alat-alat produksi yang rusak akibat kebakaran d. Masih ditemukan karyawan minum di area produksi

Minum di area produksi bukan pekerjaan yang dilarang, namun pekerja sangat membutuhkan minum saat para pekerja merasa kelelahan dan membutuhkan cairan agar rasa kelelahan bisa terhilangkan.

Tetapi saat minum pekerja harus melihat kondisi tempat terlebih dahulu saat melakukan minum di area produksi, karena jika saat melakukan minum dan air tersebut terjatuh/tumpah bisa menyebabkan konsleting listrik pada mesin sehingga bisa menyebabkan kecelakaan kerja seperti kesetrum dan mesin tersebut akan rusak karena tumpahan air tersebut. Kerugiannya bisa menyebabkan tidak berjalannya produksi dikarenakan mesin tersebut rusak dan membutuhkan perbaikan.

e. Kurangnya alat pemadam api ringan

Kurangnya alat pemadam api ringan/APAR tidak menyebabkan kecelakaan saat bekerja, namun alat terebut bisa memadamkan api yang baru muncul sehingga bisa mengurangi resiko terjadinya kebakaran saat bekerja.

f. Plafon atau atap yang sudah rusak

Plafon/atap yang sudah rusak menyebabkan kebocoran saat terjadinya hujan, sehingga terjadinya banjir di area produksi dan bisa menyebabkan kebakaran, kesetrum karena konsleting listrik yang 
disebabkan oleh air dan membuat mesin- diakibatkan lantai yang licin. mesin menjadi rusak..

Kerugian yang di dapat untuk para karyawan adalah bisa menyebabkan kesetrum akibat konsleting listrik dan menyebabkan kebakaran sehingga menjadi kehilanggan pekerjaan dan kematian. Untuk perusahaan kerugian yang didapat adalah terjadinya kerugian karena alat-alat produksi rusak sehingga membutuhkan perbaikan dan berhentinya produksi sehingga target produksi tidak tercapai dengan waktu yang sudah ditentukan oleh customer.

g. Kabel-kabel yang tidak tersusun dengan rapih

Kabel-kabel yang tidak tersusun dengan rapih resiko yang terjadi adalah para pekerja bisa menyebabkan kecelakaan kerja dikarenakan kabel-kabel yang tidak tersusun dengan rapih tersebut sehingga para pekerja terjatuh, dan bisa menyebabkan kabel tersebut putus dan mesin produksi mendapatkan kerusakan dan membutuhkan perbaikan.

h. Lantai produksi yang licin

Lantai di area produksi yang licin diakibatkan kebocoran/ tumpahan/ ceceran dari mesin yang menyebabkan lantai di area tersebut menjadi licin, Resiko yang terjadi akibat lantai di area produksi yang licin bisa menyebabkan terjadinya kecelakaan kerja bagi para pekerja yaitu terpeleset dan terjatuh

\section{Solusi Untuk Menghindari Terjadinya}

\section{Kecelakaan Kerja Berdasarkan} Permasalahan Yang Ditemukan

a. Tidak tersedianya alat pelindung diri (APD)
1) Perusahaan menyediakan Alat Pelindung Diri (APD).
2) Para pekerja dengan sadar diri menggunakan Alat Pelindung Diri.
3) Perusahaan mengawasi para pekerja untuk menggunakan Alat Pelindung diri.
4) Perusahaan memberikan hukuman kepada para karyawan yang tidak menggunakan Alat Pelindung Diri
5) Parusahaan merawat Alat Pelindung Diri (APD)

b. Ventilasi udara yang tidak berfungsi

Pihak perusahaan memperbaiki ventilasi udara yang sudah tidak berfungsi

c. Masih ditemukan karyawan merokok di area produksi

1) Para karyawan agar sadar diri untuk tidak merokok di area produksi, yang sudah diingatkan menggunakan rambu-rambu dilarang merokok

2) Perusahaan mengawasi para pekerja untuk mencegah karyawan merokok di area produksi 
3) Perusahaan menindak tegas untuk karyawan yang melanggar ramburambu dilarang merokok.

d. Masih ditemukan karyawan minum di area produksi

1) Para karyawan agar sadar diri untuk tidak meminum di area produksi, yang sudah diingatkan menggunakan rambu-rambu dilarang makan dan minum di area produksi

2) Perusahaan mengawasi para pekerja untuk mencegah karyawan makan dan minum di area produksi

3) Perusahaan menindak tegas untuk karyawan yang telah melanggar rambu-rambu yang sudah diingatkan.

e. Kurangnya alat pemadam api ringan (APAR)

1) Perusahaan menyediakan alat pemadam api ringan/APAR yang sudah sesuai dengan denah perusahaan

2) Perusahaan merawat dengan cara mengecek rutin alat pemadam api ringan/APAR setiap bulannya.

3) Plafon atau atap yang sudah rusak

4) Perusahaan merenovasi plafon atap yang sudah rusak dan mengalami kebocoran saat hujan

f. Kabel-kabel yang tidak tersusun dengan rapih

Perusahaan mengintruksikan kepada

bagian maintenance untuk merapihkan kabelkabel yang tidak tersusun dengan rapih g. Lantai produksi yang licin

Para karyawan agar sadar diri untuk membersihkan bagian lantai yang licin, dan membersihkannya dengan intruksi yang sudah diberikan oleh pihak perusahaan Tabel $5 \mathrm{~W}+1 \mathrm{H}$

Metode 5W1H adalah seperangkat langkah sistematis untuk mengumpulkan semua data yang diperlukan buat keperluan investigasi atau penyusunan laporan tentang situasi masalah yang ada. Dengan target akhir mengidentifikasi bagian-bagian dari masalah dan secara akurat menggambarkan konteks masalah tersebut.

Analisa permasalahan K3 di PT Pantja Simpati menggunakan $5 \mathrm{~W}+1 \mathrm{H}$

\begin{tabular}{|l|l|l|}
\hline No & $5 \mathrm{~W}+1 \mathrm{H}$ & \\
\hline 1 & What? & $\begin{array}{l}\text { Para pekerja tidak } \\
\text { menggunakan alat } \\
\text { pelindung diri }\end{array}$ \\
\hline & Who? & Pekerja dan manajemen \\
\hline When? & $\begin{array}{l}\text { Saat produksi } \\
\text { berlangsung }\end{array}$ \\
\hline Where? & $\begin{array}{l}\text { PT Pantja Simpati } \\
\text { Why? }\end{array}$ & $\begin{array}{l}\text { Pihak manajemen tidak } \\
\text { menyediakan alat } \\
\text { pelindung diri }\end{array}$ \\
\hline & How? & $\begin{array}{l}\bullet \text { Pihak perusahaan } \\
\text { menyediakan alat } \\
\text { pelindung diri }\end{array}$ \\
\hline
\end{tabular}




\begin{tabular}{|c|c|c|}
\hline & & $\begin{array}{l}\text { - Karyawan agar sadar } \\
\text { diri menggunakan alat } \\
\text { pelindung diri setelah } \\
\text { disediakan } \\
\text { - Pihak manajemen } \\
\text { mengawasi para } \\
\text { pekerja untuk } \\
\text { menggunakan alat } \\
\text { pelindung diri dan } \\
\text { menindak tegas }\end{array}$ \\
\hline 2 & What? & $\begin{array}{l}\text { Ventilasi udara yang } \\
\text { tidak berfungsi }\end{array}$ \\
\hline & Who? & Manajemen \\
\hline & When? & $\begin{array}{l}\text { Saat produksi } \\
\text { berlangsung }\end{array}$ \\
\hline & Where? & Bagian Finishing \\
\hline & Why? & $\begin{array}{l}\text { Pihak manajemen tidak } \\
\text { memperbaiki ventilasi } \\
\text { udara yang sudah rusak }\end{array}$ \\
\hline & How? & $\begin{array}{l}\text { Pihak manajemen untuk } \\
\text { memperbaiki ventilasi } \\
\text { udara yang sudah tidak } \\
\text { berfungsi }\end{array}$ \\
\hline 3 & What? & $\begin{array}{l}\text { Masih ditemukan } \\
\text { karyawan merokok }\end{array}$ \\
\hline & Who? & Pekerja \\
\hline & When? & $\begin{array}{l}\text { Saat produksi } \\
\text { berlangsung }\end{array}$ \\
\hline & Where? & Bagian Produksi \\
\hline & Why? & $\begin{array}{l}\text { Karyawan tidak } \\
\text { mematuhi rambu-rambu }\end{array}$ \\
\hline
\end{tabular}

\begin{tabular}{|c|c|c|}
\hline & & dilarang merokok \\
\hline & How? & $\begin{array}{l}\text { - Manajemen } \\
\text { memperketat untuk } \\
\text { mengawasi para } \\
\text { karyawan dan } \\
\text { menindak tegas para } \\
\text { karyawan yang } \\
\text { melanggar } \\
\text { Para karyawan agar } \\
\text { sadar diri untuk } \\
\text { menaati rambu-rambu } \\
\text { dilarang merokok }\end{array}$ \\
\hline 4 & What? & $\begin{array}{l}\text { Masih ditemukan } \\
\text { karyawan minum }\end{array}$ \\
\hline & Who? & Pekerja \\
\hline & When? & $\begin{array}{l}\text { Saat produksi } \\
\text { berlangsung }\end{array}$ \\
\hline & Where? & Bagian Produksi \\
\hline & Why? & $\begin{array}{l}\text { Karyawan tidak } \\
\text { mematuhi rambu-rambu } \\
\text { dilarang makan dan } \\
\text { minum di area produksi }\end{array}$ \\
\hline & How? & $\begin{array}{l}\text { - } \text { Manajemen } \\
\text { memperketat untuk } \\
\text { mengawasi para } \\
\text { karyawan dan } \\
\text { menindak tegas para } \\
\text { karyawan yang } \\
\text { melanggar } \\
\text { - Para karyawan agar } \\
\text { sadar diri untuk }\end{array}$ \\
\hline
\end{tabular}




\begin{tabular}{|c|c|c|}
\hline & & $\begin{array}{l}\text { menaati rambu-rambu } \\
\text { dilarang merokok }\end{array}$ \\
\hline \multirow[t]{6}{*}{5} & What? & $\begin{array}{l}\text { Kurangnya alat } \\
\text { pemadam api } \\
\text { ringan/APAR }\end{array}$ \\
\hline & Who? & Manajemen \\
\hline & When? & $\begin{array}{l}\text { Saat produksi } \\
\text { berlangsung }\end{array}$ \\
\hline & Where? & Di bagian cetak Offset \\
\hline & Why? & $\begin{array}{l}\text { Pihak manajemen tidak } \\
\text { menyediakan alat } \\
\text { pemadam api ringan dan } \\
\text { tidak merawatnya } \\
\text { dengan teratur }\end{array}$ \\
\hline & How? & $\begin{array}{l}\text { Pihak manajemen } \\
\text { menyediakan alat } \\
\text { pemadam api ringan di } \\
\text { bagian produksi yang } \\
\text { kekurangan alat } \\
\text { pemadam api ringan }\end{array}$ \\
\hline \multirow[t]{6}{*}{6} & What? & $\begin{array}{l}\text { Plafon atap yang sudah } \\
\text { rusak }\end{array}$ \\
\hline & Who? & Manajemen \\
\hline & When? & $\begin{array}{l}\text { Saat produksi } \\
\text { berlangsung }\end{array}$ \\
\hline & Where? & Bagian Finishing \\
\hline & Why? & $\begin{array}{l}\text { Pihak manajemen tidak } \\
\text { merenovasi palfon/ atap } \\
\text { yang sudah rusak }\end{array}$ \\
\hline & How? & $\begin{array}{l}\text { Pihka manajemen } \\
\text { merenovasi plafon atap } \\
\text { yang rusak }\end{array}$ \\
\hline
\end{tabular}

\begin{tabular}{|c|c|c|}
\hline 7 & What? & $\begin{array}{l}\text { Kabel-kabel yang tidak } \\
\text { tersusun dengan rapih }\end{array}$ \\
\hline & Who? & Pekerja \\
\hline & When? & $\begin{array}{l}\text { Saat produksi } \\
\text { berlangsung }\end{array}$ \\
\hline & Where? & Bagian Fnishing \\
\hline & Why? & $\begin{array}{l}\text { Karyawan tidak } \\
\text { merapihkan kabel kabel }\end{array}$ \\
\hline & How? & $\begin{array}{l}\text { Para karyawan bagian } \\
\text { maintance merapihkan } \\
\text { kabel kabel yang tidak } \\
\text { tersusun dengan rapih }\end{array}$ \\
\hline 8 & What? & Lantai produksi licin \\
\hline & Who? & Pekerja \\
\hline & When? & $\begin{array}{l}\text { Saat produksi } \\
\text { berlangsung }\end{array}$ \\
\hline & Where? & Di bagian Produksi \\
\hline & Why? & $\begin{array}{l}\text { Karyawan tidak } \\
\text { membersihkan ceceran } \\
\text { minyak/oli yang } \\
\text { menyebabkan lantai licin }\end{array}$ \\
\hline & How? & $\begin{array}{l}\text { Para karyawan agar } \\
\text { sadar diri untuk } \\
\text { membersihkan bagian } \\
\text { lantai yang licin, sesuai } \\
\text { interuksi yang diberikan } \\
\text { oleh pihak manajemen }\end{array}$ \\
\hline
\end{tabular}

A. What?

What atau Apa merupakan unsur pertama yang wajib ada, sebab suatu permasalahan pasti mempunyai inti dari permasalahan tersebut, setelah penulis 
jabarkan di dalam kolom What? adalah inti permasalahan yang ditemukan di PT Pantja Simpati.

\section{B. Who?}

Who atau Siapa menunjukan bahwa pekerja atau manajemen yang melakukan kesalahan dalam melakukan penerapan keselamatan dan kesehatan kerja yang bisa menimbulkan kecelakaan kerja.

C. When?

When atau Kapan menunjukan bahwa kapan dilakukannya kesalahan penerapan keselamatan dan kesehatan kerja yang bisa menyebabkan kecelakaan kerja

D. Where?

Where atau Dimana menunjukan bahwa dimana letak permasalahan itu terjadi

E. Why?

Why atau Kenapa menunjukan sebab-sebab timbulnya permasalahan keselamatan dan kesehatan kerja di PT Pantja Simpati

F. How?

How atau Bagaimana menunjukan suatu solusi yang bisa menghindari dari permasalahan keselamatan dan kesehatan kerja di PT Pantja Simpati yang bisa menyebabkan kecelakaan kerja untuk para pekerja

\section{KESIMPULAN}

1. Berdasarkan $\mathrm{K} 3$ penulis selama praktik industri di PT Pantja Simpati, penulis mengambil kesimpulan bahwa, penerapan keselamatan dan kesehatan kerja di PT Pantja Simpati masih kurang baik karena penulis masih menemukan beberapa masalah yaitu, tidak tersedianya alat pelindung diri (APD), ventilasi udara yang tidak berfungsi, masih ditemukan karyawan merokok di area produksi, masih ditemukan karyawan minum di area produksi, kurangnya alat pemadam api ringan (APAR), plafon atau atap yang sudah rusak, kabel-kabel tidak tersusun dengan rapih, dan lantai produksi yang licin.

\section{Saran}

1. Penulis telah menemukan beberpa saran untuk mengurangi permasalahan $\mathrm{K} 3$ yang bisa menyebabkan kecelakaan kerja dan menganggu kesehatan para pekerja seperti, menyediakan alat pelindung diri (APD), menyediakan alat pemadam api ringan, memperbaiki ventilasi udara yang sudah tidak berfungsi, dan menindak tegas para karyawan yang melakukan pelanggaran terhadap rambu-rambu yang sudah diberikan oleh pihak perusahaan

\section{REFERENSI}

Cecep T, Mitha E. (2013). Kesehatan Lingkungan Dan K3. Yogyakarta: Nuha Medika. 
Vol. 8, No. 1, April 2021, hal. 48-60

Djatmiko, Riswan Dwi. (2016) Keselamatan

ress.

dan Kesehatan Kerja. Yogyakarta: Deepublish

Johanes, Steven. (2017). LK3 (Lingkungan dan Kesehatan Kerja). Makalah. Cepu: Pemasaran dan Niaga

Sujoso, Anita Dewi Prahastuti. (2012). Dasardasar Keselamatan dan Kesehatan Kerja. Jember: Jember University P
www.Safetyshoe.com Undang-undang yang mengatur mengenai $\mathrm{K} 3$.

www.Sertifikatiso.wordpress.com , ISO 45001:2016, standard kesehatan dan keselamatan kerja.

www.pakardokumen.com, $5 \mathrm{~W}-1 \mathrm{~h}$ penjelasan dan contoh. 